\title{
Légútbiztosítás koronavírus-fertőzött betegekben
}

\author{
László István dr. - Molnár Csilla dr. - Koszta György dr. \\ Végh Tamás dr. - Fábián Ákos dr. - Berhés Mariann dr. \\ Juhász Marianna dr. - Fülesdi Béla dr.
}

Debreceni Egyetem, Általános Orvostudományi Kar, Aneszteziológiai és Intenzív Terápiás Klinika, Debrecen

\begin{abstract}
A világunkon végigvonuló koronavírus-járvány számos kihívással szembesíti az egészségügyben dolgozókat. A vírus cseppfertőzéssel terjed, és magas a virulenciája, ezért minden olyan beavatkozás, mely légúti aeroszolképződést generál, potenciálisan veszélyezteti az ellátásban részt vevők egészségét. A koronavírus-fertőzés súlyos formája progresszív légzési elégtelenséggel jár, melynek ellátásában a korai endotrachealis intubáció és invazív gépi lélegeztetés elengedhetetlen. Az intubáció során fokozott a légúti aeroszolképződés veszélye, így magas az ellátó személyzet fertőződésének veszélye. Az előzőeken túl ezen betegeknél relatíve gyakori a nehéz légútbiztosítás is. Cikkünk célja, hogy gyakorlatorientált áttekintést adjon a koronavírussal fertőzött betegek légútbiztosításának specialitásairól, különös tekintettel az infekciókontroll és a betegbiztonság szempontjaira.
\end{abstract}

Orv Hetil. 2020; 161(17): 696-703.

Kulcsszavak: légútbiztosítás, nehéz légút, RSI, infekciókontroll, betegbiztonság, koronavírus, COVID, légzési elégtelenség, ARDS

\begin{abstract}
Airway management of coronavirus-infected patients
The coronavirus pandemic is a serious challenge for healthcare workers worldwide. The virus is spread through the air by droplets of moisture when people cough or sneeze and it has a very high virulence. Procedures generating airway aerosols are dangerous for every participant of patient care. The serious form of coronavirus infection can cause progressive respiratory failure. The best treatment is early endotracheal intubation and invasive mechanical ventilation. Intubation is an aerosol-generating process and thus carries the risk of contamination. Additionally the airway management of this patient population is usually difficult. The goal of this article is to give a practice-based overview of the peculiarities of airway management in coronavirus-infected patients with special regard to infection control and patient safety considerations.
\end{abstract}

Keywords: airway management, difficult airway, RSI, infection control, patient safety, coronavirus, COVID, respiratory insufficiency, ARDS

László I, Molnár Cs, Koszta Gy, Végh T, Fábián Á, Berhés M, Juhász M, Fülesdi B. [Airway management of coronavirus-infected patients]. Orv Hetil. 2020; 161(17): 696-703.

(Beérkezett: 2020. március 27.; elfogadva: 2020. március 30.)

\section{Rövidítések}

APOX $=($ apneic oxygenisation $)$ apnoés oxigenizáció; ARDS = (acut respiratory distress syndrome) heveny légzési distressz szindróma; BSA $=($ body surface area $)$ testfelszín; CAVE $=$ Figyelj!/Vigyázz!; $\mathrm{CF}=$ cysticus fibrosis; $\mathrm{CICO}=$ (can’t intubate, can’t oxygenate) sikertelen intubáció és sikertelen oxigenizáció; $\mathrm{COPD}=$ (chronic obstructive pulmonary disease) krónikus obstruktív tüdőbetegség; COVID-19 = (coronavirus disease 2019) koronavírus-betegség 2019; CPAP $=($ continu- ous positive airway pressure) folyamatos pozitív légúti nyomás; $\mathrm{CPR}=($ cardiopulmonary resuscitation $)$ cardiopulmonalis újraélesztés; DAS = (Difficult Airway Society) Nehéz Légúti Társaság (Egyesült Királyság); EKG = elektrokardiográfia; $\mathrm{ETCO}_{2}=$ (end tidal carbon dioxide) kilégzésvégi szén-dioxid (koncentrációja); ETI = endotrachealis intubáció; ETT = endotrachealis tubus; exp. $\mathrm{O}_{2}=$ (expiratory oxygene) kilégzett oxigén (koncentrációja); $\mathrm{FEV}_{1}=$ (forced expiratory volume in 1 second $) \mathrm{az}$ első másodpercben mért forszírozott exspiratorikus vitálkapa- 
citás; $\mathrm{FiO}_{2}=$ (fraction of inspired oxygen $)$ a belégzett oxigén koncentrációja; $F M V=$ (face mask ventilation $)$ arcmaszkos lélegeztetés; FONA = (front of neck access) conicotomia; HFNO = (high-flow nasal oxygen) magas áramlású, orron keresztül alkalmazott oxigénterápia; $\mathrm{HME}=$ (heat and moisture exchanger) hő- és nedvességcserélő; $\mathrm{H}_{2} \mathrm{Ocm}=$ vízcentiméter; ID = (internal diameter) belső átmérő; $1 / \mathrm{min}=$ liter $/$ perc; $\mathrm{LMA}=$ (laryngeal mask airway) gégemaszk; MODS $=$ (multiple organ dysfunction syndrome) többszervi funkciózavar szindróma; NIPPV $=($ non-invasive positive-pressure ventilation) noninvazív pozitív nyomású lélegeztetés; NIV $=$ (non-invasive ventilation) noninvazív lélegeztetés; NYHA = (New York Heart Association) New York-i Szívbetegséggel Foglalkozó Társaság; $\mathrm{O}_{2}$ = oxigén (molekula); $\mathrm{P}=$ pulzus; $\mathrm{PaO}_{2}=$ artériás oxigéntenzió; PEEP $=($ positive end-exspiratory pressure $)$ pozitív kilégzésvégi nyomás; PPE $=$ (personal protective equipment) személyi védőfelszerelés; PREOX = preoxigenizáció; PS = (pressure support) nyomástámogatás (lélegeztetés során); REOX = reoxigenizáció; RR = (Riva-Rocci) noninvazívan mért vérnyomás; RSI $=$ rapid szekvenciális indukció; $\mathrm{SAP}=($ severe acute pancreati tis) súlyos heveny hasnyálmirigy-gyulladás; SOFA = (sequential organ failure assessment) a szervi elégtelenség súlyossági pontrendszere; $\mathrm{SpO}_{2}=$ pulzoximéterrel mért oxigénszaturáció; ttkg = testtömegkilogramm; $\mathrm{UH}=$ ultrahang; $\mathrm{VC}=$ (vital capacity) vitálkapacitás; $\mathrm{VF}=$ (ventricular fibrillation) kamrafibrilláció; $\mathrm{VL}=$ videolaringoszkóp; $\mathrm{VT}=($ ventricular tachycardia $)$ kamrai tachycardia; $\mathrm{ZSMO}_{2}$ = zsákos-maszkos oxigén

\section{Fő szempontok}

- A COVID-19-fertőzött betegek légútbiztosítása során a kritikus állapotú betegekre vonatkozó általános szabályok fokozottan érvényesek.

> A betegbiztonság és az infekciókontroll (cseppfertőzéssel terjedő kórokozók elleni védelem) egyidejü jelentősége.

> Az első intubációs kísérlet biztonságos sikerére való törekvés.

$>$ Egységes, mindenki által ismert/megtanult/begyakorolt/alkalmazott technikai és nem technikai kompetenciák a beavatkozás minden lépésére vonatkozóan.

$>$ A tervezés/előkészítés jelentősége, ellenőrző lista (1. táblázat), illetve kognitív segédeszközök használata (1. ábra).

> Hatékony/zárt láncú kommunikáció.

- A fentieken túl, az alábbi speciális körülményekre kell figyelemmel lennünk:

$>$ Az ITO erőforrásait nagyban terhelő, egy időben jelentkező magas esetszám miatt az életkilátások alapos mérlegelése javasolt intubációt/invazív gépi lélegeztetés kezdését megelőzően.

$>$ A betegség magas virulenciája miatt az ellátásban részt vevők fokozott fertőzésveszélynek vannak kitéve, melyet az alábbi szempontok figyelembevételével mérsékelhetünk:

- Csökkentsük az ellátó személyzet expozícióját a beteg légutaiból óhatatlanul kilépő kórokozó ágens vonatkozásában:

\section{1. táblázat | COVID-19, ETI-ellenőrző lista}

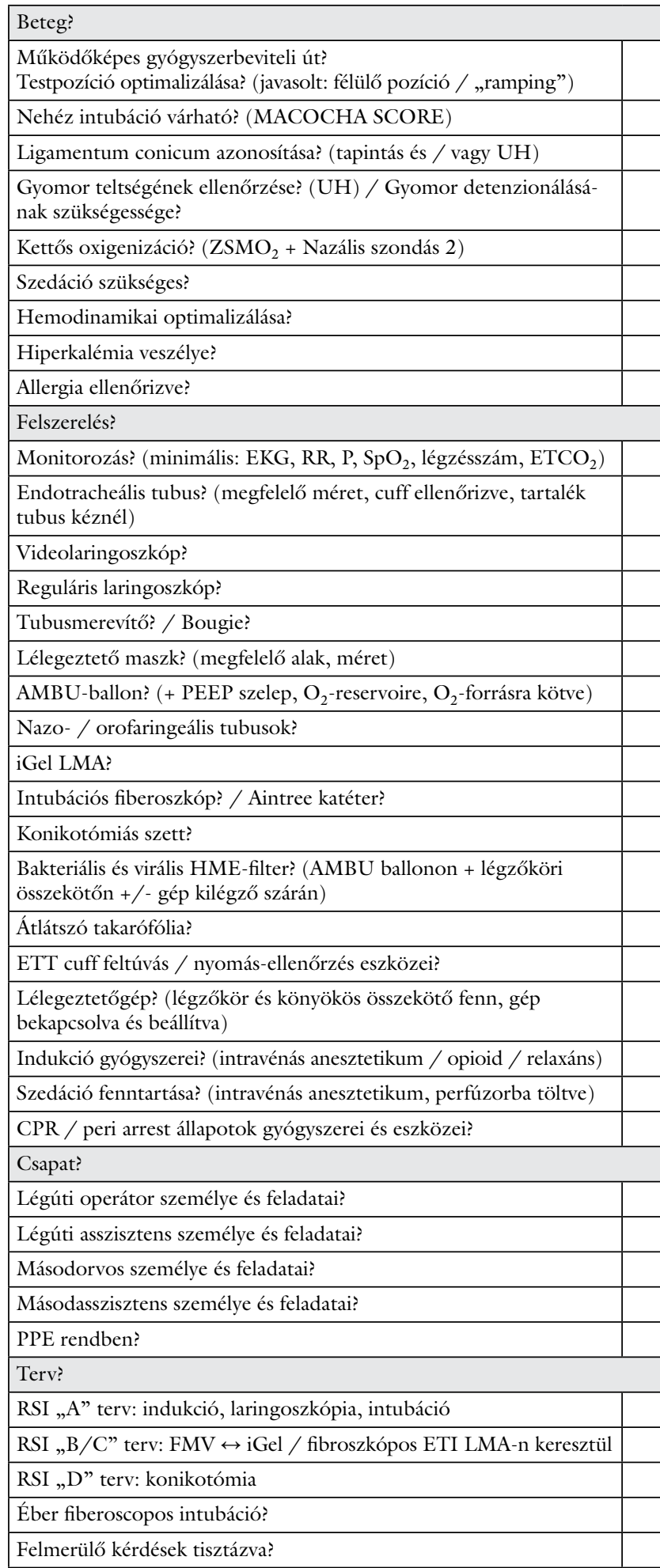

CAVE = Figyelj! /Vigyázz!; COVID-19 = koronavírus-betegség 2019; $\mathrm{CPR}$ = cardiopulmonalis újraélesztés; $\mathrm{EKG}=$ elektrokardiográfia; $\mathrm{EtCO}_{2}=$ kilégzésvégi szén-dioxid (koncentrációja); ETI = endotrachealis intubáció; ETT = endotrachealis tubus; FMV = arcmaszkos lélegeztetés; $\mathrm{HME}=$ hö- és légcserélö; LMA = gégemaszk; $\mathrm{O}_{2}=$ oxigén (molekula); $\mathrm{P}=$ pulzus; $\mathrm{PEEP}=$ pozitív kilégzésvégi nyomás; $\mathrm{PPE}=$ személyi védőfelszerelés; $\mathrm{RR}=$ noninvazívan mért vérnyomás; RSI = rapid szekvenciális indukció; $\mathrm{SpO}_{2}=$ pulzoximéterrel mért oxigénszaturáció; $\mathrm{UH}=$ ultrahang; $\mathrm{ZsMO}_{2}=$ zsákos-maszkos oxigén 


Kritikus állapotú COVID
betegek endotracheális
intubációja
(DAS ajánlás alapján)
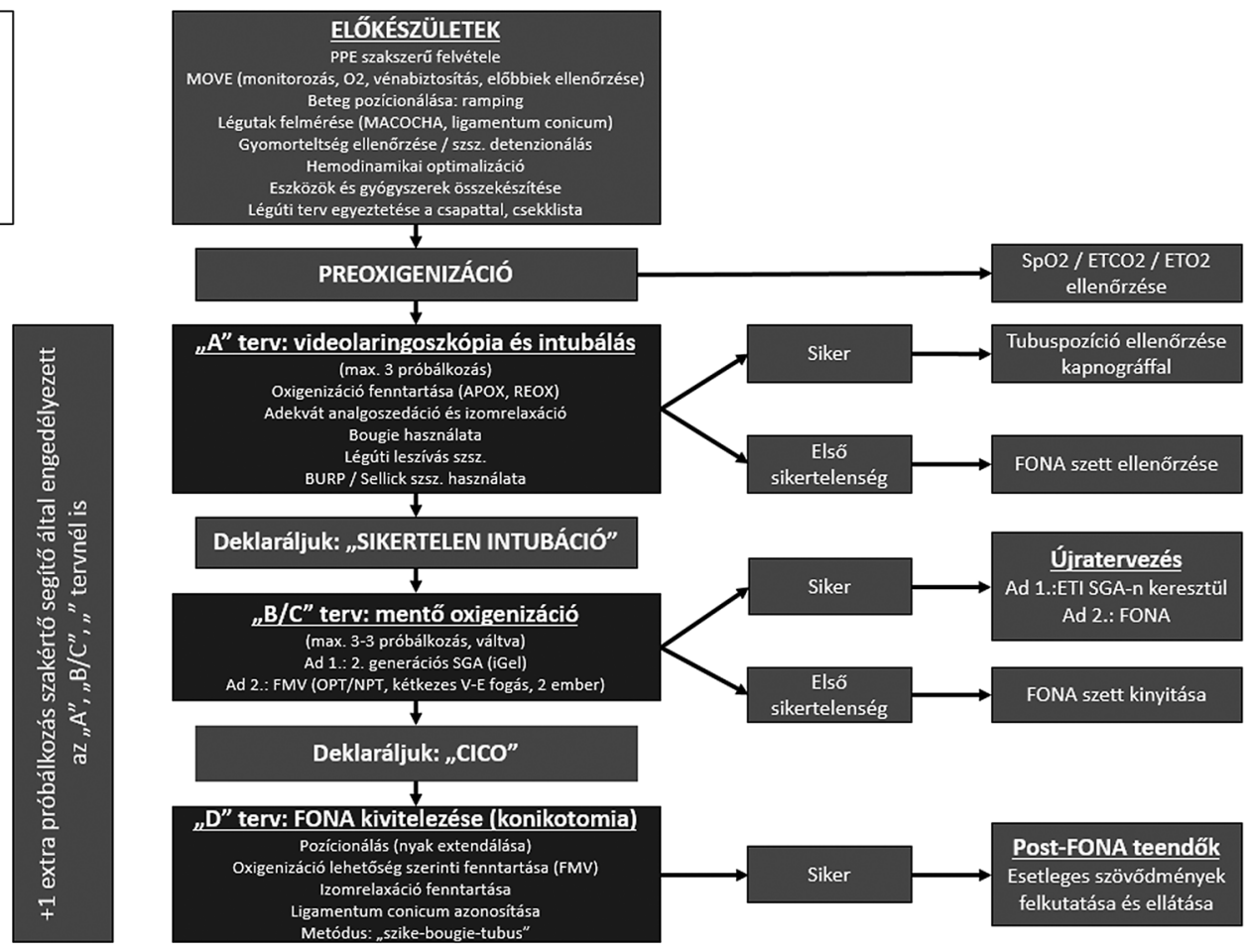

Deklaråljuk: „SIKERTELEN INTUBÁCIÖ
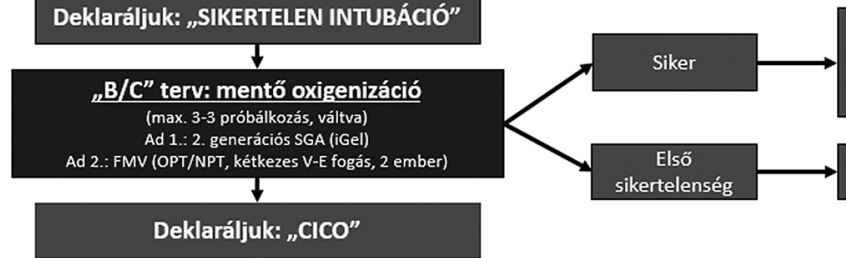

Úiratervezés

Ad 1.:ETI SGA-n keresztï Ad 2.: FONA
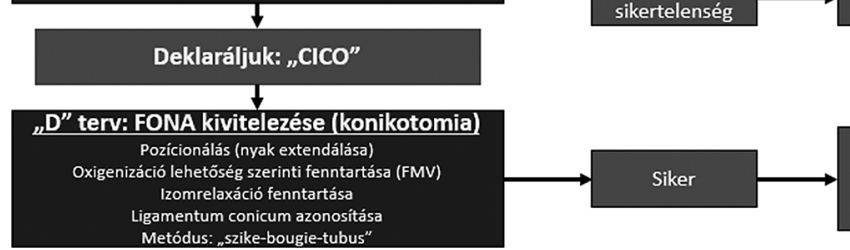

APOX = apnoés oxigenizáció; CICO = sikertelen intubáció és sikertelen oxigenizáció; COVID-19 = koronavírus-betegség 2019; DAS = Nehéz Légúti Társaság (Egyesült Királyság); ETI = endotrachealis intubáció; $\mathrm{ETCO}_{2}=$ kilégzésvégi szén-dioxid (koncentrációja); FMV = arcmaszkos lélegeztetés; FONA = conicotomia; $\mathrm{O}_{2}=$ oxigén (molekula); $\mathrm{REOX}=$ reoxigenizáció; $\mathrm{SGA}=\mathrm{SpO}_{2}=$ pulzoximéterrel mért oxigénszaturáció

- A betegek légútbiztosítását (lehetőleg negatív nyomású, esetleg zárt neutrális nyomású) izolációs helyiségben végezzük.

- Az ellátásban részt vevő személyek létszámát korlátozzuk a minimálisan szükségesre.

- Légútbiztosítás során az abban részt vevőknek az elérhető legmagasabb szintű egyéni védőeszközöket kell viselniük.

- Preferáljuk az egyszer használatos eszközök alkalmazását.

- Videolaringoszkóp (mellyel már kellő gyakorlatot szereztünk) használata már az első intubációs kísérlet során.

- Minimalizáljuk a légútbiztosítás során az aeroszolképződést, illetve előzzük meg annak kijutását a beteg légutaiból.

- A NIV/HFNO, illetve a maszkos-ballonos lélegeztetés lehetőség szerinti kerülése, illetve használatának minimalizálása.

- Az intubációt az abban legtapasztaltabb személy végezze.

- Intubáció adekvát analgoszedáció és mély izomrelaxáció mellett.

- Az éber fiberoszkópos intubáció lehetőség szerinti kerülése.

- Gastricus tubus levezetése az intubálást megelőzően csak abszolút szükséges esetben javasolt.

- Bakteriális és virális HME-filter kötelező használata.

- Zárt rendszerü légúti leszívás alkalmazása.
- Membrános port alkalmazása a bronchoszkópia során. - A tubus és a lélegeztetőgép tervezett diszkonnekciója során a tubus lefogása javasolható.

- A tracheostomia lehetőség szerinti mellőzése.

\section{Az endotrachealis intubáció (ETI) indikációjával kapcsolatos megfontolások}

- Légzési elégtelenség jelei esetén a KORAI ETI javasolt. Kritériumok:

$>$ Súlyos légzési elégtelenség.

- Hypoxaemia:

- $\mathrm{SpO}_{2}<75 \%$ körlevegőn és/vagy <90\% magas áramlású (>10 l/min) $\mathrm{ZSMO}_{2}$ mellett.

- $\mathrm{PaO}_{2}<40 \mathrm{Hgmm}$ körlevegőn, illetve Horowitz-index $\left(\mathrm{PaO}_{2} / \mathrm{FiO}_{2}\right)<200 \mathrm{O}_{2}$-terápia mellett (az egyes $\mathrm{O}_{2}$-terápiás eszközök által biztosított $\mathrm{FiO}_{2}$ tekintetében) (2. táblázat).

- Légzésszám>30/min nyugalomban és/vagy a légzőizmok kimerülése (jele: respiratoricus/kevert acidosis).

Progresszíven romló légzési elégtelenség.

> Képalkotó vizsgálatokkal ARDS-re utaló eltérések.

- CAVE: bedside tüdő-UH kiemelt jelentősége; 3 fenotípus:

- UH „wet”: lung-sliding megtartott, vizsgálati ablakonként >2 B-vonal, mindkét oldalon, diffúzan $\rightarrow$ NIV megpróbálható (ld. alább). 
2. táblázat $\mid$ Az egyes $\mathrm{O}_{2}$-terápiás eszközök által biztosított $\mathrm{FiO}_{2}$ (forrás: http://dndeducators.com)

\begin{tabular}{|c|c|c|}
\hline Eszköz & $\mathrm{O}_{2}$-áramlás $(\mathrm{l} / \mathrm{min})$ & Biztosított $\mathrm{FiO}_{2}(\%)$ \\
\hline \multirow[t]{6}{*}{ Orrszonda } & 1 & 25 \\
\hline & 2 & 29 \\
\hline & 3 & 33 \\
\hline & 4 & 37 \\
\hline & 5 & 41 \\
\hline & 6 & 45 \\
\hline \multirow[t]{5}{*}{ Egyszerü arcmaszk } & 6 & 35 \\
\hline & 7 & 41 \\
\hline & 8 & 47 \\
\hline & 9 & 53 \\
\hline & 10 & 60 \\
\hline \multirow{3}{*}{$\begin{array}{l}\text { Rezervoáros arcmaszk } \\
\text { visszalégzést gátló } \\
\text { szeleppel }\end{array}$} & $10-15$ & $\begin{array}{l}2 \text { oldalszelep } \\
\text { eltávolítva: } 80-85\end{array}$ \\
\hline & & $\begin{array}{l}1 \text { oldalszelep } \\
\text { eltávolítva: } 85-90\end{array}$ \\
\hline & & $\begin{array}{l}\text { Mindkét oldalszelep } \\
\text { a helyén: 95-100 }\end{array}$ \\
\hline \multirow[t]{6}{*}{ Venturi maszk } & kék & 24 \\
\hline & fehér & 28 \\
\hline & narancs & 31 \\
\hline & sárga & 35 \\
\hline & vörös & 40 \\
\hline & zöld & 60 \\
\hline $\begin{array}{l}\text { Magas áramlású } \\
\text { orrszonda }\end{array}$ & $\max .60$ & $21-100$ \\
\hline
\end{tabular}

$\mathrm{FiO}_{2}=$ a belégzett oxigén koncentrációja $\mathrm{O}_{2}=$ oxigén (molekula)

- UH „dry”: lung-sliding redukált (pleuralis adhaesiók), illetve kétoldali multiplex subpleuralis konszolidációk $\rightarrow$ korai ETI és invazív lélegeztetés indokolt.

- UH „mixed”: kevert UH-kép $\rightarrow$ korai ETI és invazív lélegeztetés indokolt.

> Légzési elégtelenséghez társuló MODS jelei.

- NIV (NIPPV) és HFNO NEM JAVASOLT.

A NIV és a HFNO fokozza a légúti aeroszolképződést, ezáltal a cseppfertőzés veszélyét, mely az infekciókontroll szempontjából nemkívánatos.

> A nem megfelelő körültekintéssel végzett NIV és HFNO maszkírozhatja a légzési elégtelenség romlásának klinikai jeleit, így lehet, hogy a betegeknél megkésve kezdjük az invazív lélegeztetést.

> NIV (NIPPV) megfontolható az alábbi kitételekkel:

- Az invazív gépi lélegeztetés elérhetősége korlátozott.

- NIV-helmet (sisak) elérhető - a cseppfertőzés veszélye ezáltal csökkenthető.

- A tüdő-UH-kép „wet”.

- A beteg hemodinamikailag stabil, éber, jól kooperál.
- Amennyiben a beteg állapota 1 órán belül nem mutat egyértelmú javulást vagy romlik, azonnali ETI és invazív gépi lélegeztetés javasolt.

- A várható életkilátások mérlegelése minden esetben ajánlott az intubációt megelőzően.

> CAVE: etikai megfontolások, illetve a korlátozott eszközpark optimális felhasználása.

ETI/invazív gépi lélegeztetés iniciálása, illetve intenzív terápiás ellátás NEM javasolt az alábbiak fennállása esetén:

- Súlyos, előrehaladott, az orvostudomány jelenlegi állása szerint inkurábilis alapbetegség („end-stage” állapotok):

- Aktív, metasztatikus malignitás (<6 hónap életkilátással).

- Krónikus tüdőbetegség (például COPD, CF, tüdőfibrosis, amikor már bázis- $\mathrm{PaO}_{2}<55 \mathrm{Hgmm} /$ házi $\mathrm{O}_{2}$ igény áll fenn, $\mathrm{FEV}<25-30 \%$ vagy $\mathrm{VC}<60 \%$, illetve ha másodlagos pulmonalis hypertonia áll fenn).

- Pangásos bal- vagy jobbszívfél-elégtelenség (NYHA III-IV.).

- Májelégtelenség (Child-Pough-pontszám>7).

- Immundeficientia opportunista patogének okozta fertőzéssel.

- Dementia (önellátásra képtelen).

- Progresszív neuromuscularis betegség (például izomdisztrófia).

- Igazolt/valószínúsíthető COVID-betegnél fellépő olyan súlyos (COVID okozta heveny légzési elégtelenségtől független) akut betegség, melyből a felépülésre az adott körülmények között a maximális ellátás ellenére is csekély az esély.

- Keringés- és légzésleállás (ismeretlen időpontú kezdet, nem sokkolandó ritmus, sokkrefrakter VF/VT, illetve visszatérő 'arrest' esetén a CPR elkezdésének/folytatásának indoka is erősen kérdéses).

- Bármilyen más heveny állapot (például politrauma, $>40 \%$ BSA-égés, SAP stb.), amikor az iniciális SOFApontszám>11.

- Az intubáció megfelelő izolálóhelyiségben (lehetőség szerint negatív nyomású környezetben vagy normál nyomású, zárt helyiségben) történjen; pozitív nyomású helyiség használata kerülendő a vírus szóródásának megelőzése céljából.

- Az intubáció lehetőség szerint TERVEZETTEN, ne sürgős beavatkozásként történjen.

\section{A légútbiztosítási team előkészítése}

- Lehetóleg csak a minimálisan szükséges létszámú csapat vegyen részt a beavatkozásban.

- Lehetőleg ne osszuk be a légútbiztosítási teambe azokat a munkatársakat, akik különösen hajlamosak a légúti fertőzésekre: 
$>65$ (60) évesek.

> Krónikus légzőszervi betegségben szenvednek.

Immunkompromittáltak.

$>$ Várandósak.

- Az előkészületek során osszuk ki a szerepeket, határozzuk meg az egyes szereplők pontos feladatát, és közösen állítsuk fel a légútbiztosítási tervet.

> Légúti operátor

- A team tagjai közül az emelt szintú légútbiztosításban legtapasztaltabb személy.

- Az elérhető legmagasabb szintú személyi védőfelszerelést (PPE) kell viselnie.

- A beteg fejvégénél helyezkedik el.

- Feladata a beteg intubálása és a lélegeztetés megkezdése.

\section{Légúti asszisztens}

- A légúti eszközöket és protokollokat tökéletesen ismerô intenzív terápiás/aneszteziológiai szakasszisztens.

- Az elérhető legmagasabb szintű PPE-t kell viselnie.

- A beteg oldalánál helyezkedik el.

- Feladata a beteg intubálása során történő múszerelés és gyógyszerelés, a monitorok észlelése, illetve segítség az esetleg szükséges CPR kivitelezésében.

\section{$>$ Másodorvos}

- Emelt szintû légútbiztosításban (különösképp fiberoszkópos intubációban és conicotomiában) járatos személy.

- Az elérhető legmagasabb szintű PPE-t kell viselnie.

- A légúti asszisztenssel szemben, a beteg oldalánál helyezkedik el (nem korlátozva az előző két ember mozgását).

- Feladata: segítséget nyújt a légúti operátornak összetett légúti manőverek során (például Sellick-manőver regurgitatio esetén, manuális in-line stabilizáció a nyaki gerinc instabilitása esetén, conicotomia, fiberoszkópos intubálás stb.), illetve az esetleg szükséges CPR kivitelezésében.

\section{Másodasszisztens}

- A légúti eszközöket és protokollokat tökéletesen ismerô segítő.

- Az izolálóhelyiségen kívül helyezkedik el, oda nem léphet be.

- Csak sebészeti maszk és munkakesztyú viselése kötelezó.

- Feladata: az izolálóhelyiségben nem található eszközök beadása, a PPE-be való beöltözés és az abból való kiöltözés ellenőrzése, dokumentáció.

\section{Személyi védőfelszerelés (PPE) használata}

- A betegellátásban részt vevő személyek cseppfertőzés elleni védelmének legfontosabb eleme.
- Javasolt az elérhető legmagasabb szintű PPE használata a beteggel közvetlenül érintkező ellátók számára ETI alatt.

- A beöltözés/kiöltözés a betegellátást szolgáló izolálóhelyiséggel közvetlenül szomszédos előkészítő helyiségben történjen.

- Dedikált személy (másodasszisztens) ellenőrizze a helyes kivitelezését.

- A szükséges védőeszközöknek és a beöltözés/kiöltözés menetének tekintetében ld. az általánosan elérhető protokollokat.

\section{Eszközök, gyógyszerek, a beteg előkészítése és ellenőrzése}

\section{- Minimálisan szükséges eszközök}

(Preferáljuk az egyszer használatos eszközöket; a többször használatos eszközök tisztításával kapcsolatosan maximális gondossággal járjunk el!)

> Légúti eszközök

- ETI „A” tervhez (a beteghez odakészítendő eszközök):

- A beteg arcára jól illeszkedő lélegeztetőmaszk (preoxigenizációhoz).

- Nazális $\mathrm{O}_{2}$-kanül (apnoés oxigenizációhoz).

- Ambu-ballon HME-filterrel, PEEP-szeleppel, $\mathrm{O}_{2}$-rezervoárral és $\mathrm{O}_{2}$-összekötőcsővel vagy Mapleson $\mathrm{C}$ („100-as”) kör (az intubációs kísérletek közti reoxigenizációhoz).

- Videolaringoszkóp (lehetőleg szeparált kijelzővel).

- Hagyományos laringoszkóp (a VL meghibásodásának esetére, különféle lapocokkal).

- Endotrachealis tubusok (különféle méretekben: 6,08,5 ID).

- Flexibilis tubusmerevítő.

- Bougie.

- ETI „B/C” tervhez (az izolálóhelyiségen belül elhelyezkedő, azonnal elérhető eszközök):

- iGel (vagy más intubációra alkalmas) LMA különféle méretekben.

- LMA-n keresztüli intubálásra alkalmas külső átmérőjű ETT-k.

- Könyökös tubusösszekötő membrános porttal.

- Bougie vagy tube exchange catheter.

- Aintree-katéter (lehetőség szerint).

- Flexibilis endoszkóp szeparált monitorral (például Ambu aView monitor és egyszer használatos aScope Slim fiberoszkóp).

- Ambu-ballon HME-filterrel, PEEP-szeleppel, $\mathrm{O}_{2}$-rezervoárral és $\mathrm{O}_{2}$-összekötőcsővel vagy Mapleson $\mathrm{C}$ („100-as”) kör (az LMA-behelyezési kísérletek közti reoxigenizáció céljából).

- Naso- és oropharyngealis tubusok (különféle méretekben, maszkos-ballonos lélegeztetéshez).

- ETI „D” tervhez (CICO esetén; conicotomiás szett - az izolálóhelyiségen belül elhelyezkedő, azonnal elérhető eszközök): 
- Szike (lehetőleg 10-es méretü, „hasas” penge).

- Bougie.

- Endotrachealis tubus (6,0 ID reguláris vagy tracheostomiás tubus).

$>$ Egyéb eszközök

- ETI-segédeszközök (beteghez odakészítendók):

- Légúti leszívókatéter, összekötő cső, gyưjtőtartály, múködő vákuum.

- 10 ml-es fecskendő (ETT-ballon felfújásához).

- ETT-ballon-nyomásmérő (manuális vagy elektronikus).

- Tubusrögzítő gézszalag (vagy dedikált rögzítőeszköz).

- Fiberoszkóp páramentesító oldat/síkosító.

- Átlátszó takarófólia (az ETI alatt a beteg fejének és felsőtestének ezzel történő takarása csökkenti a cseppfertőzés veszélyét).

- Gépi lélegeztetéshez szükséges eszközök (beteghez odakészítendők):

- Magas tudású lélegeztetőgép egyszer használatos légzőkörrel felszerelve, bekapcsolva, beállítva, készenlétben.

- Bakteriális és virális HME-filter (ETT/LMA/lélegeztető arcmaszk, illetve légzőkör/lélegeztetőballon közé való illesztése KÖTELEZŐ, a kilégzőszár és a lélegeztetőgép közé megfontolandó).

- Zárt rendszerú leszívó, összekötő cső, gyưjtőtartály, múködő vákuum.

- Gyógyszeres indukcióhoz szükséges eszközök (beteghez odakészítendők):

- Fecskendők $(5,10,20,50 \mathrm{ml})$.

- Felszívótúk.

- Fecskendő-összekötő cső.

- Fecskendős perfúzor.

- A betegmonitorozás eszközei (a betegre szakszerűen felhelyezve).

- Ultrahangkészülék (potenciális szerepe ETI során: a gyomor teltségének megítélése; a ligamentum conicum lokalizációja; az ETT-pozíció megítélése).

- A CPR eszközei (az izolálóhelyiségen belül, azonnal elérhetően):

- Defibrillátor.

- Mechanikus mellkaskompressziós eszköz (LUCAS).

- Minimálisan szülkséges gyógyszerek

> Intravénás anesztetikumok (a légúti operátor döntése alapján; a beteg mellett, megfelelően előkészítve):

- Ketamin (elsőként választandó).

- Dózis: 1-2 mg/ttkg.

- Propofol (csak hemodinamikailag relatíve stabil betegeknél).

- Dózis: $1 \mathrm{mg} / \mathrm{ttkg}$.

$>$ Kábító fájdalomcsillapító (a légúti operátor döntése alapján; a beteg mellett, megfelelően előkészítve; ketamin mellé nem szükséges):
- Fentanil.

- Dózis: 2-3 $\mu \mathrm{g} / \mathrm{ttkg}$.

- Szufentanil.

- Dózis: 0,2-0,3 $\mu \mathrm{g} / \mathrm{ttkg}$.

$>$ Izomrelaxáns (a légúti operátor döntése alapján; a beteg mellett, megfelelően előkészítve):

- Rokuronium (elsődlegesen választandó).

- Dózis: 1,2 mg/ttkg.

- Szukcinilkolin.

- Dózis: 1-2 mg/ttkg.

- Nyálkahártya-érzéstelenítő (éber fiberoszkópos intubációhoz):

- Lidocain krém (a fiberoszkóp szárára kenve), esetleg spray (CAVE: köhögés).

$>\mathrm{CPR} /$ 'peri-arrest' állapotok ellátásának gyógyszerei (az izolálóhelyiségen belül, azonnal elérhetően, megfelelően előkészítve).

- A betegre vonatkozó előkészités

> MOVE (Monitorozás-Oxigenizáció-VénabiztosításEllenőrzés):

- A vitális paraméterek (minimálisan: $\mathrm{SpO}_{2}$, légzésszám, RR, P, EKG, ETCO ${ }_{2}$ ) Monitorozásának biztosítása.

- A beteg Oxigenizációjának lehetőség szerinti fenntartása $\rightarrow$ KETTŐS oxigenizáció: magas áramlású (>10 1/min) $\mathrm{ZSMO}_{2}$-vel párhuzamosan alacsonyabb áramlású (<6 1/min) nazális $\mathrm{O}_{2}$ alkalmazása (ez utóbbi ETI alatt az apnoés oxigenizációt is szolgálja).

- A gyógyszerbeviteli út/Vénakanül biztosítása (ha még nincs).

- A fentiek rendszeres Ellenőrzése.

$>$ Hemodinamikai optimalizáció (lehetőleg).

$>$ A beteg pozicionálása („ramping”: a felsőtest megemelve, a nyak flektálva, a fej extendálva).

$>$ A gyomor teltségének ellenőrzése $\rightarrow$ hasi UH (konvex UH-fejjel, a beteg félülő pozíciójában, epigastrialisan, az UH-fejet saggitalisan tartva, a gyomor antrumát vizsgálva - CAVE: kellő gyakorlat).

- A gyomor üres (ritka): a regurgitatio/aspiráció veszélye csekély.

- A gyomorban folyadék és/vagy szolid tartalom észlelhető (gyakori): a regurgitatio/aspiráció veszélye fokozott.

- Ha van még időnk a hatását kivárni, metoklopramid adható.

- Nagyobb mennyiségű tiszta folyadék jelenléte esetén, amennyiben regurgitatióra hajlamosító egyéb állapot (például diabetes, obesitas, várandósság stb.) ismert, a detenzionálás gyomorszonda segítségével megfontolandó (CAVE: a köhögés, cseppfertőzés fokozott veszélyét mérlegelni kell, emellett a szonda ronthatja a lélegeztetőmaszk tömítettségét preoxigenizáció során).

- A Sellick-manóver megfontolandó ETI során.

A légutak vizsgálata, nehéz légút előrejelzése (például MACOCHA-pontszám) (3. táblázat). 
3. táblázat | MACOCHA-pontszám

\begin{tabular}{ll}
\hline Faktor & pont \\
\hline A beteggel kapcsolatos krónikus kondíciók & 5 \\
\hline Mallampati-pontszám III-IV. & 2 \\
\hline Obstruktív alvási apnoe & 1 \\
\hline A nyaki gerinc korlátozott mobilitása & 1 \\
\hline A szájnyitás korlátozottsága $(<3 \mathrm{~cm})$ & 1 \\
\hline Az aktuális betegséghez kapcsolódó faktorok & 1 \\
\hline Kóma & 1 \\
\hline Súlyos hypoxaemia $($ SpO $2<80 \%)$ & \\
\hline A légúti operátorhoz kapcsolódó faktor & \\
\hline A légúti operátor nem aneszteziológus & \\
\hline Értékelés: $0-12$ & \\
\hline $0:$ intubációs nehézség nem várható & \\
\hline 12: intubációs nehézség biztosan várható & \\
\hline
\end{tabular}

$\mathrm{SpO}_{2}=$ pulzoximéterrel mért oxigénszaturáció

\section{Az ETI menete}

- Nehéz légút NEM várható: RSI-protokoll szerinti ETI.

> Preoxigenizáció (légúti operátor által kivitelezve).

- ZSMO $\mathrm{ZM}_{2}$ eltávolítását követően azonnal kezdve.

- Jól illeszkedő, manuálisan (kétkezes V-E fogással) rögzített lélegeztetőmaszkon keresztül.

- Megfelelően beállított (spontán légzés, $\mathrm{FiO}_{2}$ 100\%, légzési perctérfogathoz illesztett frissgáz-áramlás, PEEP/CPAP: $0 \mathrm{H}_{2} \mathrm{Ocm}$ ) lélegeztető- vagy altatógép segítségével.

- Minimum 3 perc normál térfogatú légvételekkel vagy minimum 1 perc maximális térfogatú légvételekkel.

- A $\mathrm{SpO}_{2}$ és az exp. $\mathrm{O}_{2}$ (oxigenizáció), illetve $\mathrm{ETCO}_{2}$ (alveolaris ventiláció) folyamatos ellenőrzése mellett.

- Amennyiben a fenti módszerrel a $\mathrm{SpO}_{2}$ - és az exp. $\mathrm{O}_{2}$ érdemi javulása nem érhető el, CPAP $\left(5 \mathrm{H}_{2} \mathrm{Ocm}\right)$, esetleg PS ( $\left.10 \mathrm{H}_{2} \mathrm{Ocm}\right)$ alkalmazható addig, amíg a $\mathrm{SpO}_{2}$ emelkedik (CAVE: pozitív nyomású noninvazív lélegeztetés által fokozott aeroszolképződés).

$>$ A preoxigenizáció alatt frakcionált szedáció (például tört dózisú propofol/ketamin bolusok) szükséges lehet nagyfokú agitáltság esetén.

> A beteg fejének és felsőtestének átlátszó fóliával való fedése.

$>\mathrm{Az}$ indukcióhoz adekvát mélységű analgoszedáció és izomrelaxáció szükséges (a behatási idő betartásával).

> Az apnoés oxigenizáció (nazális szonda, $\mathrm{O}_{2}$-áramlás max. $6 \mathrm{l} / \mathrm{min}$ ) légúti instrumentáció alatt megfontolandó, DE csak akkor, ha VL-t használunk (CAVE: a magasabb $\mathrm{O}_{2}$-áramlások cseppfertőzést fokozó hatása).

> A maszkos-ballonos lélegeztetés lehetőség szerinti kerülése (csak markáns deszaturáció esetén javasolható); kivitelezése a legjobb tömítettséget biztosító, 2 kezes
V-E maszkfogási technikával javasolt (a másodorvos segítségével, aki a ballont kezeli).

Sellick-manőver csak manifeszt regurgitatio esetén (dedikált személy által).

> Videolaringoszkóp használata már az első kísérlet során is javasolt (OK: nagyobb sikerráta; a cseppfertőzés veszélye kisebb, mivel távolabb van egymástól a beteg és az operátor arca).

$>$ Sikertelenség/váratlan nehéz légúti szituáció: DAS „B/C” és „D” terv szerinti ETI.

- Nehéz légút várható: éber fiberoszkópos intubáció.

> Csak akkor, ha más megoldás nincs (CAVE: köhögés / cseppfertőzés veszélye).

> Nyálkahártya-érzéstelenítés Lidocain kenőcs, esetleg spray használatával; kerüljük a nebulizátor alkalmazását.

> Frakcionált szedáció; opioidok (a legjobb: remifentanil) adása megfontolandó (antitussiv hatás).

$>$ Javasolt flexibilis endoszkóp szeparált monitorral (például Ambu aView monitor és egyszer használatos aScope Slim vagy Regular fiberoszkóp).

\section{A tubussal kapcsolatos egyéb teendők}

- HME-filter (+ zárt rendszerú leszívó) haladéktalan felhelyezése.

- A pozíció ellenőrzése: elsődlegesen az $\mathrm{ETCO}_{2}$-görbe alapján, esetleg (ha amúgy is használtuk ETI kapcsán) fiberoszkóp vagy UH segítségével - amennyiben a tubuspozíció kétséges, a tubus eltávolítását követően azonnali reintubáció szükséges.

- A tömítettség ellenőrzése: a 'cuff' nyomás lehetőleg $\mathrm{NE}$ legyen $>30 \mathrm{H}_{2} \mathrm{Ocm}$. Tömítetlenség észlelése esetén (magasabb légúti nyomások) a 'cuff' nyomás a haszon (a cseppfertőzés veszélye csökken) és a kockázat (nyálkahártya-ischaemia) mérlegelése után $30 \mathrm{H}_{2} \mathrm{Ocm}$ fölé emelhető.

- Tubusrögzítés gézszalaggal vagy dedikált rögzítőeszközzel.

- A tubus és a légzőkör felesleges diszkonnekciójának kerülése.

- Zárt rendszerü szívó használata rendszeres légúti leszívás során.

> Membrános porttal rendelkező légúti összekötő az esetleges bronchoszkópia kivitelezéséhez.

- Amennyiben a beteget átmenetileg le kell vennünk a gépről, a HME-filter maradjon a tubuson \pm a tubust fogjuk le 'pean' [érszorító csipesz] (az utóbbi spontán légzés megléte esetén nem javasolt).

\section{Az extubációval kapcsolatos megfontolások}

- A beteg extubációja (a szokványos leszoktatást követően) ideális esetben akkor történjen, amikor az illető már nem fertőző. 
- Amennyiben ez nem biztosítható, az extubáció standard eljárásrendjét az alábbiak figyelembevételével kell végezni:

$>$ A beteg $\mathrm{O}_{2}$-igényét extubációt követően $\mathrm{ZSMO}_{2}$ adagolásával tudni kell biztosítani.

$>$ NIV (NIPPV)/HFNO extubációt követően sem javasolt.

D Az extubációs team felépítése és felszerelése (PPE) az intubáció során leírtakkal megegyező legyen.

$>$ Az esetlegesen szükséges reintubációhoz mindent oda kell készíteni.

> Extubációt megelőzően preoxigenizáljuk a beteget pár percig $100 \% \mathrm{FiO}_{2}$-vel, a lélegeztetőgépen keresztül.

A garatot nyílt, a tracheát zárt rendszerü szívóval tisztítsuk le, mielőtt kihúzzuk a tubust.

$>$ A diszkonnekciót közvetlenül megelőzően helyezzük készenlétbe a lélegeztetőgépet.

$>$ A diszkonnekció során a HME-filtert hagyjuk az ETT-n.

> A zárt rendszerú szívót a tracheába vezetve és bekapcsolva húzzuk ki a tubust a rögzítés feloldása és a ballon leengedése után (ezáltal a gégebemenet és ballon közti térben rekedt váladékot is el tudjuk távolítani a kihúzás során).

A beteget ne köhögtessük extubáció alatt/után opioid (a legjobb: remifentanil) frakcionált adása megfontolandó.

> Extubációt követően a betegre azonnal fel kell adni a $\mathrm{ZSMO}_{2}$-t (megfelelő mennyiségü $\mathrm{O}_{2}$ biztosítása mellett véd a cseppfertőzéstől is).

Anyagi támogatás: A közlemény megírása anyagi támogatásban nem részesült.
Szerzői munkamegosztás: L. I.: A kézirat elkészítése. M. Cs., K. Gy., V. T., F. Á., B. M., J. M.: A közlemény szerkesztése. F. B.: A kézirat jóváhagyása. A cikk végleges változatát valamennyi szerző elolvasta és jóváhagyta.

Érdekeltségek: A szerzőknek nincsenek érdekeltségeik.

\section{Irodalom}

[1] Brewster DJ, Chrimes NC, Do TB, et al. Consensus statement: Safe Airway Society principles of airway management and tracheal intubation specific to the COVID-19 adult patient group. Med J Aust. 2020 Mar 16. [Epub ahead of print]

[2] Alhazzani W, Møller MH, Arabi YM, et al. Surviving sepsis campaign: guidelines on the management of critically ill adults with coronavirus disease 2019 (COVID-19). Intensive Care Med. 2020 Mar 28. Doi: 10.1007/s00134-020-06022-5. [Epub ahead of print]

[3] Wax RS, Christian MD. Practical recommendations for critical care and anesthesiology teams caring for novel coronavirus (2019-nCoV) patients. Can J Anaesth. 2020 Feb 12. 1-9. Doi: 10.1007/s12630-020-01591-x. [Epub ahead of print]

[4] Peng PW, Ho PL, Hota SS. Outbreak of a new coronavirus: what anesthetists should now. Br J Anesth. 2020 Feb 27. Doi: 10.1016/j.bja.2020.02.008. [Epub ahead of print]

[5] Wang C, Horby PW, Hayden FG, et al. A novel coronavirus outbreak of global health concern. Lancet 2020; 395: 470-473.

[6] Higgs A, McGrath BA, Goddard C, et al. Guidelines for the management of tracheal intubation in critically ill adults. $\mathrm{Br} \mathrm{J}$ Anaesth. 2020; 120: 323-352.

[7] Cheung WK, Myburgh J, Seppelt IM, et al. A multicentre evaluation of two intensive care unit triage protocols for use in an influenza pandemic. Med J Aust. 2012; 197: 178-181.

(László István dr., Debrecen, Nagyerdei krt. 98., 4032 e- mail: lacipityu@gmail.com)

A cikk a Creative Commons Attribution 4.0 International License (https://creativecommons.org/licenses/by/4.0/) feltételei szerint publikált Open Access közlemény, melynek szellemében a cikk bármilyen médiumban szabadon felhasználható, megosztható és újraközölhető, feltéve, hogy az eredeti szerző és a közlés helye, illetve a CC License linkje és az esetlegesen végrehajtott módosítások feltüntetésre kerülnek. (SID_1) 